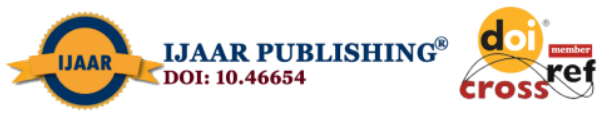

International Journal of Advanced Academic Research (Arts, Humanities and Education) | ISSN: 2488-9849

Vol. 6, Issue 12 (December, 2020)|www.ijaar.org

Journal DOI: 10.46654/ij.24889849

Article DOI: 10.46654/ij.24889849.a61253

\title{
PARENTAL AND PEER INFLUENCES ON ATTITUDE TOWARDS COUNSELLING AMONG STUDENTS OF CAC THEOLOGICAL SEMINARY, AKURE
}

\author{
ABIODUN Kayode David, Ph.D \\ CAC Theological Seminary, Akure. \\ kayode2david @gmail.com \\ OGUNWUYI Babatunde Oyeyemi, Ph.D \\ CAC Theological Seminary, Akure. \\ ogunwuyib1@gmail.com \\ ADEJIMOLA Iwalewa Olasunkanmi \\ CAC Theological Seminary, Akure. \\ 08033951712
}

\begin{abstract}
Positive attitude of students towards counselling is necessary in any level of education. Many studies had investigated self-esteem, social-economic status, emotional intelligence on attitude towards counselling of students in secondary schools but not in theological colleges. This study however investigated parental and peer factors as determinants of attitude towards counselling of students in CAC Theological Seminary, Akure. All students were used for the study. Reliable instruments were used to collect information from the respondents. Parental Factors Scale $(r=$ 0.75), Peer Influence Scale $(r=0.74)$ and Attitude Towards Counselling Scale $(r=0.85)$ were used for data collection. Pearson product moment and multiple regression analysis were used for data analysis. The result shows that peer influence was related to $(r=.365)$ while parental influence $(r=.122)$ did not relate to attitude toward counselling of students in CAC Theological seminary. The independent variables jointly contributed to students' attitude towards counselling (Adjusted $R^{2}=1.09, F_{2}=5.261$ ) and accounted to $13.4 \%$ contribution to attitude towards counselling. The parental influence $(=-.025)$ did not contribute to students' attitude towards counselling while peer influence $(=3.75)$ contributed to students' attitude toward counsellings. It is recommended that parents of student should be more helpful in motivating the students to seek counselling and parents should train their children on how to associate themselves to friends who could help them to seek counsel in appropriate place for good performance in life and ministry.
\end{abstract}

Keywords: Parental influence, Peer influence, Attitude towards Counselling, CAC Theological Seminary, Akure. 


\section{Introduction}

Counseling in a layman language is an helping profession. It is an effort of someone to help another person to solve his or her problem by giving him/her suggestions and practical experiences. Professionally, counseling is a process of applying psychological principles and techniques to solve human problems. It is a therapeutic relationship between an expert in behavioural science and a person who is having behavioural problem in any area of life such as vocation, educational, socio-personal (religious, health, spiritual etc) areas.

In a religious perspective, counseling is a process of combining religious, principles, doctrines, literature (Bible) and method and psychological principles, empirical counseling procedures and techniques to deal with the problem of religion and other life problems (Natonàl Policy on Counseling, 2018). Counseling is the organised efforts of school as family, hospital and industries to help an individual to develop his potential to a maximum level in order to function effectively in all areas of his/her life (Lokoyi, 2015).

Counseling is purposely initiated to enforce investment of human development, social and psychological, physical, religious well-beings of people. It alleviates problem, promote interpersonal relationship, cooperation, good health and sound minds. Counseling is essential for all categories of people in Nigeria that is why it is included on the National Policy on Education (2013) and National Policy on Counseling (2018) respectively. The Theological Seminary and Colleges are not excluded in the policy because the policy emphasized that faith-based organisations which are not venture and independent of state can initiate, implement and promote counseling services (National Policy on Counseling, 2018).

Since it is a policy that religious organisation should organize and implement counseling services, CAC Theological Seminary is of no exception and the attitude of students towards counselingis important to their academic performance. Attitude and disposition of the students to counselling can be favourable or unfavourable because counseling is part of the pastoral services to be rendered.

Many studies on attitude towards counseling had shown that attitude of school management affected counseling (Achebe, 1986). Socio-economic status, gender and other factors (Komiyam and Eeills, 2001) and emotional intelligence and self-esteem (Lokoy1, 2015) were empirically investigated on attitude towards counseling among others. The past studies had neglected the influence of parental and peer factors on attitude of counselling among theological students.

\section{Literature Review}

Parental influence in this study means the influence of biological parents, guidance or supporters or sponsors of theological education of the students while peer influence indicated the influence of friends and school mates in and out of the seminary. Seeking counselling has been influenced by family and societal roles. It is believed in some societies that counselling is Western world philosophy equivalent to hospitalization (Chowdhury, 2000). The family, relative, neighbours share responsibility of counseling for a child life's and well-beings. 
They provide stability and support when problem emanates and maintain physical and psychological integrity of individual family member (Carson and Chowdbury, 2000). The individual family and other family affiliations determine seeking of counselling (Arshad, 2010).

Furthermore, in real sense of view, parental participation in students' education encouraged school works, study time and modeled desired behaviour in reading, counselling among others (Olatoye and Ogunkola, 2008) and parental counselling efforts prevented collapsing of education of students in all levels of education (Adebowale, 2012) parental and teachers influence on the choice of business subjects in school as result of proper counselling and guidance has been shown in study of Marcus (2017) and parental monitoring and time engagement, parental supports and monitoring were related to academic achievements of students (Keane and Topor, 2010 and Azua, 2016), while Catsambis (2008) showed that parental influence negatively associated with students academic performance and parental influence did not influence academic performance of students (Koskel, 2014).

On the other hand, peer influence has been seen to be more stronger than that of parents. Peer group influences the what students value, know, wear, eat and learn the influence can also be determined by age, personality and nature of group (Tope, 2012) and peer can influence choice of subjects (Owoyele and Toyobo, 2008).Chen (2005) also showed that peers influence academic achievement of students indirectly and Barker (2011) submitted that teen are rarely influenced by their peers to do something and desire to do anything is within the teenager. Then, Makuma (2010) submitted that peer influence has nothing to do with students' attitude towards school but peer influence contributed to academic performance of students (Korir and Kipkemboi ,2014).

\section{Objective of the study}

The main objective of the study is to investigate the parental and peer influence on attitude toward counselling among students of CAC Theological Seminary, Akure.

The specific objectives are to:

i. Find out the joint contribution of parental and peer influences on attitude toward counselling among students of CAC Theological Seminary, Akure.

ii. Determine the relative contributions of parental and peer influences on attitude towards counselling among students of CAC Theological seminary, Akure.

\section{Research Questions}

The following research questions were raised and answered in the study.

i. What is the joint contribution of parental and peer influences on attitude towards counselling among students of CAC Theological seminary Akure.

ii. What are the relative contributions of parental and peer influences on attitude towards counselling among students of CAC Theological seminary Akure.

\section{Hypotheses}

The null hypotheses were analysed at 0.05 level of significance. The hypotheses are; 
$\mathrm{HO}_{1}$ : There is no significant relationship between parental influence and attitude towards counselling among students of CAC Theological Seminary, Akure

$\mathrm{HO}_{2}$ : There is no significant relationship between peer influence and attitude towards counselling among students of CAC Theological Seminary, Akure.

\section{Methods}

\section{Research Design}

Descriptive research design of correlation type was adopted for the study.

\section{Population of the Study}

The population of the study comprises one hundred and five students (105) of the CAC Theological Seminary

\section{Sample and Sampling Technique}

The researchers used total enumeration since the population is accessible to the researchers.

\section{Research Instrument}

A structured questionnaire was used to collect necessary information for the study. The questionnaire was tagged parental and peer influences on attitude towards counseling questionnaire (PPIATCQ). The questionnaire was sub-divided into four sections.

Section A: Demographic variables. The demographic variables comprised age, gender and class.

Section B: Parental influence scale (PIS). The parent influence scale developed by the researchers was used to elicit information from the respondents. The typical items are: my sponsor checks my academic work frequently, my guidance like counseling and encourage me to seek it.

It consists of 10 items structured in 4 Likert format ranging from strongly agree (4) to strongly disagree (1). The reliability coefficient of the scale was 0.75 through test- re - test within interval of two weeks.

Section C: Peer Influence scale (PIS). It was constructed by the researchers. The scale was used to elicit information on peer influence in seeking counseling among students. The typical items are:

My friends influence me to visit counselor, I feel comfortable with friends who like counselling. It was 10 item scale with 4 Likert format ranging from Strongly Agree (4) to strongly Disagree (1). The reliability coefficient of the scale is 0.78 using test-re-test within interval of two weeks.

Section D: Attitude towards counseling scale (ATCS). The scale was constructed by Salami (1996) and was used to elicit information on students' attitude towards counselling. The typical items of the scale are: Based on my impressions, I will not hesitate to visit the school counselor and psychologists probe too deeply into people's lives among others. It was 16 item scale with 5 
likert scale ranging from strongly agree (5) to strongly disagree (1). The reliability coefficient of 0.82 after test-re-test for two weeks interval.

\section{Procedure for Data Collection}

The instrument was administered by the researchers with the assistance of the class governors. Out of the 105 questionnaires administered only 89 were retrieved and 71 were found valid for analysis.

\section{Method of Data Analysis}

Multiple regression analysis was adopted to analyse the two research questions raised on the study and pearson product moment correlation was used to analyse the two hypotheses in the study.

\section{RESULT}

\section{DATA ANALYSIS AND DISCUSSION OF FINDINGS}

\section{Demographic Variables}

Table 1: Frequency distribution of respondents by age

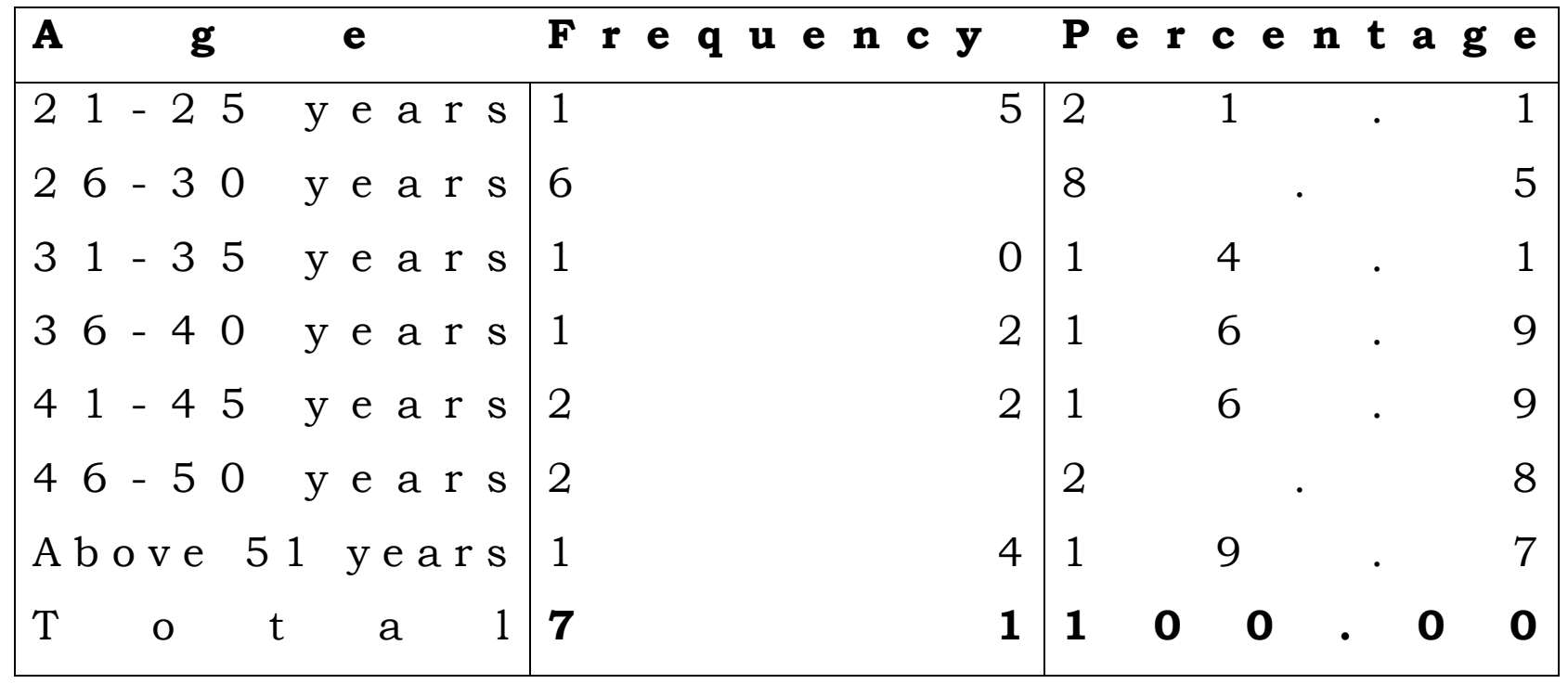

Table 1: shows that $15(21.1 \%)$ of the respondents were between $21-25$ years, $6(8.5 \%)$ were within 26-30 years, $10(14.1 \%)$ were between $31-35$ years, $12(16.9 \%)$ were between 3640 years, $22(16.9 \%)$ were between $41-45$ years, $2(2.8 \%)$ were between $46-50$ years and $14(19.7 \%)$ were 51 years and above . 
Table 2: Frequency distribution of respondents by gender

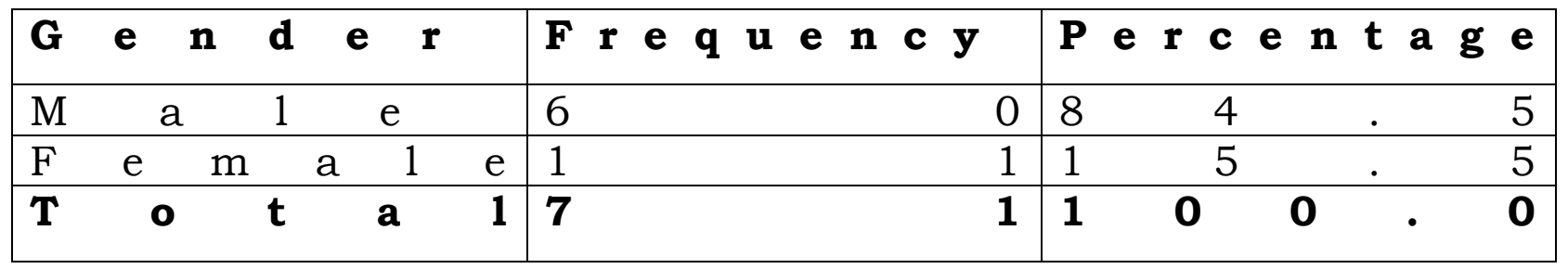

Table 2, shows that $60(84.5 \%)$ respondents were male and their female counterparts were $11(15.5 \%)$

Table 3: Frequency distribution of respondents' level of Study

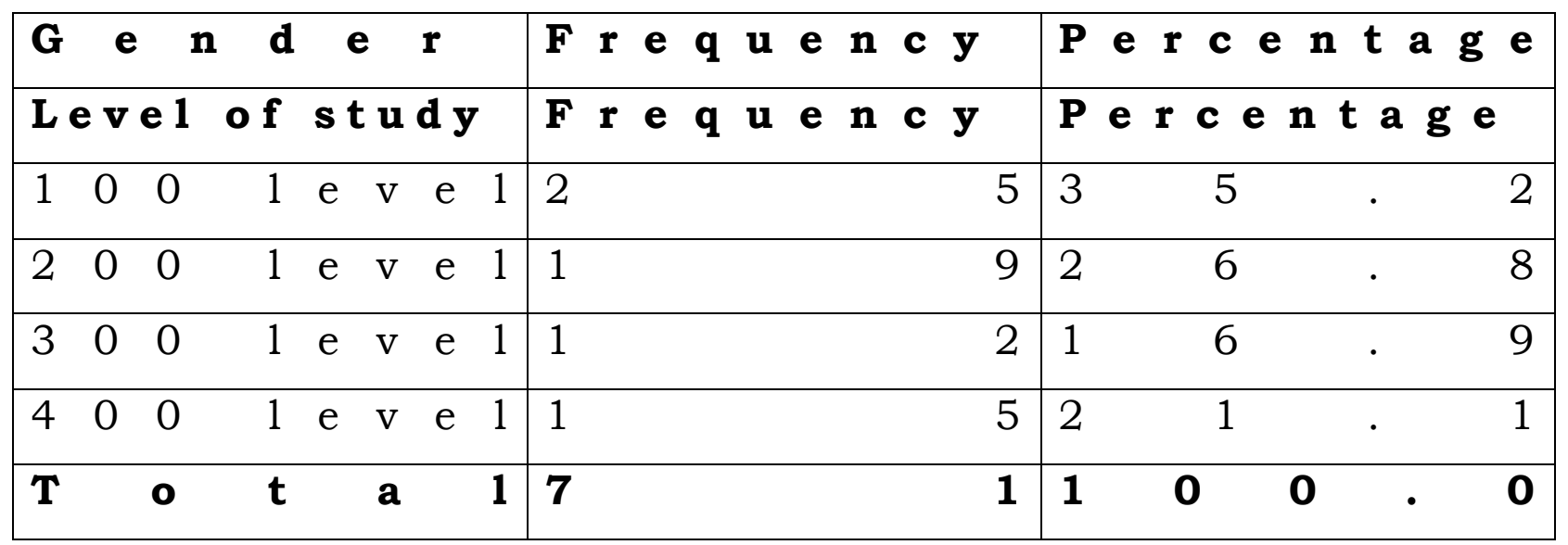

Table 3 shows that 25(35.2) respondents were in 100 level, 19(26.8\%) were in 200 level, 12 $(16.9 \%)$ were in 300 level, and $15(21.1 \%)$ were in 400 level.

Hypothesis one: There is no significant relationship between peer influence and attitude towards counselling in Christ Apostolic Church Theological Seminary, Akure.

Table 4: Pearson Product Moment Correlation (PPMC) showing the relationship between peer influence and attitude towards counseling

\begin{tabular}{|c|c|c|c|c|c|c|}
\hline $\begin{array}{llllllll}\mathbf{V} & \mathbf{a} & \mathbf{r} & \mathbf{i} & \mathbf{a} & \mathbf{b} & \mathbf{l} & \mathbf{e}\end{array}$ & M e $\quad \mathbf{a} \quad \mathbf{n}$ & Std.Dev. & $\mathbf{n}$ & $\mathbf{R}$ & $P$ - valve & Remark \\
\hline Peer Influence & 27.8169 & 6.3971 & & & & \\
\hline Attitude towards counseling & 58.1972 & 10.4862 & 7 & $.365 *$ & $0 \quad 0 \quad 2$ & S i g. \\
\hline
\end{tabular}

*Sig. at 0.05 level

It is shown in table 4 that there is a significant relationship between peer influence and attitude towards counselling in Christ Apostolic Church Theological Seminary $(\mathrm{r}=.365, \mathrm{n}=71, \mathrm{p}(.002)<$ 0.05). Hence, peer influence had a positive influence on the attitude of students towards counseling in the study.

The hypothesis is rejected. 
Hypothesis Two: There is no significant relationship between parental influence and attitude towards counseling in Christ Apostolic Church Theological Seminary, Akure.

Table 5: Pearson product Moment Correlation (PPMC) showing the relationship between Parental influence and attitude towards counseling

\begin{tabular}{|c|c|c|c|c|c|c|}
\hline 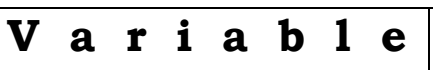 & M e a n & Std.Dev. & $\mathbf{n}$ & $\mathbf{R}$ & P - valve & Remark \\
\hline Parental Influence & 29.9577 & 6.0908 & & & & \\
\hline Attitude towards ce & 58.1972 & 10.4862 & $\begin{array}{ll}7 & 1\end{array}$ & .122 & 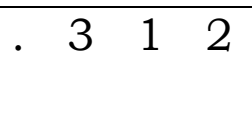 & Not Sig \\
\hline
\end{tabular}

It is shown in table 5 that there is no significant relationship between parental influence and attitude towards counselling in Christ Apostolic Church Theological Seminary, Akure $(r=0.122, n$ $=71, \mathrm{p}(.312)>0.05)$. Hence, parental influence did not affect students' attitude towards counseling in the study.

The hypothesis is accepted.

Hypothesis three: There is no significant joint contribution of parental influence and peer influence attitude towards counseling in Christ Apostolic Church Theological Seminary, Akure.

Table 6: Summary of Regression analysis showing joint contribution of parental influence and peer influence attitude towards counseling in Christ Apostolic Church Theological Seminary Akure.

\begin{tabular}{|c|c|c|c|c|c|c|c|}
\hline $\mathrm{R}$ & & R Square & & Adjusted R & Square & Std. Error o & the Estimate \\
\hline 3 & 6 & .13 & 4 & $1 \quad 0$ & 9 & 9.9 & $\begin{array}{lll}0 & 0 & 8 \\
\end{array}$ \\
\hline $\mathbf{A}$ & $\mathbf{N}$ & & & $\mathbf{O}$ & $\mathbf{v}$ & & $\mathbf{A}$ \\
\hline M o d e 1 & Sum of Squares & D & $\mathbf{F}$ & Mean Square & $\mathbf{F}$ & S i $g$. & Remark \\
\hline Regression & 1031.421 & 2 & & 515.710 & 5.261 & .008 & $\mathrm{~S}$ i g. \\
\hline Residual & 6665.819 & 6 & 8 & 98.027 & & & \\
\hline $\mathrm{T} \quad \mathrm{o} \quad \mathrm{t}$ a 1 & 7697.239 & 7 & 0 & & & & \\
\hline
\end{tabular}

Table 6: shows that joint contribution of the two independent variables (peer influence and parental influence) to the prediction of the dependent variable (i.e. attitude towards counseling). The table also shows a coefficient of multiple correlation $\left(\mathrm{R}=.366\right.$ and a multiple $\mathrm{R}^{2}$ of .134 . This means that $13.4 \%$ of the variance was accounted for by two predictor variables when taken together. The significance of the composite contribution was tested at $=0.05$. The table also shows that the analysis of variance for the regression yielded F-ratio of 5.261 (significant at 0.05 level). This implies that the joint contribution of the independent variables to the dependent variables was significant and that other variable not included in this model may have accounted for the remaining variance. 
Journal DOI: 10.46654/ij.24889849

Hypothesis four: There is no significant relative contribution of parental influence and peer influence attitude towards counseling in Christ Apostolic Church Theological Seminary, Akure.

\begin{tabular}{|c|c|c|c|c|}
\hline M o d e 1 & Unstandardized Coefficient & Standardized Coefficient & $\mathbf{T}$ & $\begin{array}{llll}\mathbf{S} & \mathbf{i} & \mathbf{g} & \text {. }\end{array}$ \\
\hline
\end{tabular}

\begin{tabular}{|c|c|c|c|c|c|}
\hline & B & Std. Error & Beta Contribution & & \\
\hline$(\mathrm{C} o \mathrm{nst}$ a $\mathrm{nt}$ ) & 42.375 & 6.708 & & 6.317 & .000 \\
\hline Peer influence & .615 & .201 & .375 & 3.060 & .003 \\
\hline Parental influence & $-4.265 \mathrm{E}-02$ & .211 & -.025 & -.202 & .840 \\
\hline
\end{tabular}

Table 7: Reveals the relative contribution of the independent variables to the variable, expressed as beta weights, viz: Peer influence $(=.375, \mathrm{p}<.05)$, and parental influence $((=.025, \mathrm{p}<.05)$

respectively. Hence, it could be deduced that peer influence was significant i.e could independently and significantly predict attitude towards counselling in Christ Apostolic Church Seminary Akure, while parental influence could not.

\section{Discussion of Findings}

Parental influence did not relate to the attitude of students towards counselling based on the result of the analysis. It means the influence of the sponsor, guardian and benefactors of the CAC Theological Students did not affect the attitude of the students toward seeking counseling in the seminary. This study supports that of Koskel (2014) and Catsambis (2008) that parental involvement and influence did not relate to academic pursuits and performance of students but contradicts. Marcus (2017), Keane and Topor (2010), Azua (2016) found that parental factor was related to seeking counseling, academic achievement among others. It can be explained that students received counseling in the school based on their own need, but not by parental influence.

On the other hand, peer influence was related to attitude towards seeking counseling among students in CAC Theological Seminary, Akure because there was relationship between peer influence and attitude of students toward going and obtaining for counseling. This finding supports Owoyele and Toyobo (2008) and Tope (2012) that peer group influenced attitude of students in both academic and other life activities but the finding contradicts Makuma (2010) that peer influence has nothing to do with students' attitude towards school. It can then be seen that peers or friends attitude towards counseling can also encourage other friends or peer to seek counseling. The peers knowledge, understanding and purpose and success received in counseling motivated others to seek counseling in CAC Theological Seminary, Akure.

The parental and peer influences jointly contributed to attitude towards counselling among among students of CAC Theological Seminary, Akure. It means parental influence in addition to peer influence promoted attitude of students towards receiving counseling. Parental beliefs in counseling and the encouragement given to the students to receive counseling for them to have a good impact in 
their academic and ministerial assignments with friends and peer group experiences in counseling assisted and influenced the students to have dispositions towards counseling.

This outcome is remarkable because there is scarcity of student on parental and peer influence on attitude of students towards receiving or seeking counseling in theological seminary.

Moreover, on relative contributions of parental and peer influences on attitude towards counselling among students of Theological Seminary, Akure. It was discovered that peer influence relatively contributed to attitude towards counseling while parental influence did not contribute. It could be discussed that students obeyed peer group laws and regulation more than parental law or regulations. It is then easy for the students to be influenced by the peers or friends peer group influence in counseling is prominent because peers influence choices of subjects (Owoyele and Toyobo, 2008) and academic activities of others (Chen, 2005; Korir and Kipkemboi 2014), but Adebowale 2012 and Arshad, (2010) in contrast showed that parents influence seeking of counseling of individuals in the family.

\section{Conclusion}

Based on the outcomes of the study, it is then concluded that parental and peer influence jointly contributed to attitude towards counseling of students of CAC Theological Seminary, Akure. Really, only peer influence was related and relatively contributed to attitude towards counseling among students of CAC Theological Seminary, Akure, but parental influence did not relate and relatively contribute to attitude towards counseling. Relevant studies were used to support and contradict the current study.

\section{Recommendations}

Based on the findings of the study, the following are recommended.

i Parents (Sponsors, guardian, benefactors of students of Theological education) should see the need to motivate their theological students to value and receive counseling because of its unmeasurable benefits to good performance in theological education and ministry assignments.

ii. The theological students should be encouraged to relate with serious and productive students in order for them to be influenced positively.

iii. Counselors in Theological Seminaries or College of Theology should regularly organize seminar for their students on the need to receive counseling for better ministry efficiency and effectiveness.

iv. Parents should be sensitised by the church authority to encourage their members in theological seminary to seek counseling through workers, good women and men of faith seminars and conferences organize annually.

\section{References}


Adebowale, T.A. (2012) Guidance and Counseling in the sustainability of Educational System. African Research Review. An International Multidiscipline, journal, Ethiopia 6(2): 215-225.

Arshad, M. (2010). Predictor of Attitude toward seeking counseling help among Indian University Students. A case study of Jawaharlal Nehra University, New Delhi, India. An unpublished, Dissertation.

Azua, (2016). Relationship between peer support, parental support and academic achievement of secondary school students in Giwa Educational zone, Kaduna State. An unpublished, M. Ed Dissertation, Amadu Bello, University, Zaria.

Barkar, J. (2011). Teens and Peer Pressure. Retrieved on 28th January 2014 from www.web.com

Carson and Chowdbury, (2000) in M. Arshad (2010) Predictors of Attitude towards seeking counseling help among Indian University Students: A Case study of Jawaharial Nehral University, New Delhi, India, unpublished Dissertation Retrieved on www.google.com on 27th January, 2020.

Chen, J.J. (2005). Relation of Academic support from parents, teacher and peers to Hong Kong Adolescents Achievement. The mediating role of Academic Engagement. Genetic and Social Psychology 13(2), 77-127.

Federal Ministry of Education (2018) National policy on counselling, 1st edition. Federal Ministry of Education (2013). National Policy on Education 6th Edition.

Keane, S.P and Topor, D.R. 2010 parental monitoring/time management and Academic Performance: a multiple meditational analysis. Retrieved from www.ncbi.nlm.nih.gov.

Komiya, N and Eeills, T.G. (2001). Predictors of Attitude towards seeking counseling among International Students. Journal of College Counseling 4, (153-160).

Korir, D.K. and Kip Kemboi, F. 2014. The School Environment and Peer Influence on Students' Academic International Journal of Humanities and Social Science 5(1) 240-252.

Koskei, B.K. (2014). Influence of parental involvement on student's Academic Performance of Public and public mixed Day Secondary Schools in Kuresoi Sub-country, Nakunu Kenya. International Journal of Education and Research 2(12), 505 - 516.

Lokoyi, O.N. 2015 Influence of psychological factors on the attitude towards Guidance and Counseling of Secondary School Students in Ibadan North Local Government Area. B.Ed project, Department of Guidance and Counseling, University of Ibadan, Ibadan.

Makuma, E. (2010). Peer Group Influence, Alcohol Consumption and Secondary School Attitude towards school. Retrieved on 22nd February, 2016 from www.google.com.

Marcus, L.B. (2017). Influence of parents teachers and peer groups on students' choice of Business Subjects in Government Secondary Schools, Kaduna State, Nigeria. 
Olatoye, R.A. and Ogunkola, B.J. (2008), Parental Involvement, Interest in schooling and science Achievement of Junior Secondary School Students in Ogun State. Journal of College Teaching Method Style, Retrieved on 12th April 2019 at www.clute institute online journals.

Owoyele, J.W and Toyobo, O.M. (2008) Parental will, peer pressure, Academic Ability and School, subjects selection by Students in Senior Secondary Schools. The Social Science 3(8) 583-586.

Salami, S.O. (1996): Attitude towards counseling among students in Nigeria. Ife Psychological 6(7) $116-131$.

Tope, O. (2011). The Influence of Peer Group on Adolescents' Academic Performance. A case study of Some Selected School in Ogun State. Unpublished Project. Retrieved from www.google.com. 